\title{
A Study on the Block Shear Strength according to the Layer Composition of and Adhesive Type of Ply-Lam CLT ${ }^{1}$
}

\author{
Gyu Woong $\mathrm{CHOI}^{2} \cdot$ Seung Min $\mathrm{YANG}^{2} \cdot \mathrm{Hyun}$ Jae $\mathrm{LEE}^{2} \cdot$ Jun Ho $\mathrm{KIM}^{2}$ • \\ Kwang Hyeon $\mathrm{CHOI}^{3} \cdot \operatorname{Seog}$ Goo $\mathrm{KANG}{ }^{2, \dagger}$
}

\begin{abstract}
In this study, a block shear strength test was conducted to compare and analyze the strength and failure mode on the glued laminated timber, CLT, and Ply-lam CLT, which are mainly used for the construction of wood construction as engineering wood. Through this, the Ply-lam CLT manufacturing conditions for optimum production, such as the type of lamina, plywood, adhesive, and layer composition, were investigated. The results are as follow. Through block shear strength test, it showed high strength in the order of glued laminated timber, Ply-lam CLT and CLT. In particular, the shear strength of Ply-lam CLT, which is made of a composite structure of larch plywood and larch lamina, passed $7.1 \mathrm{~N} / \mathrm{mm}^{2}$, which is a Korean industrial standards for block shear strength of structural glued laminated timber. In addition, in this study, there was no different in shear strength according to the adhesive type used for glulam, CLT, and Ply-lam CLT adhesion. However, in the case of Ply-lam CLT, the difference in shear strength of Ply-lam CLT was shown according to the type of lamina and plywood. The results showed high strength in the order of Larix kaempferi $>$ Mixed light hardwood $\fallingdotseq$ Pinus densiflora, sieb, et, Zucc plywood. The optimal configuration of Ply-lam CLT is when larch plywood and larch lamina are used, and it is decided that the adhesive can be used by selecting PRF and PUR according to the application. The results of block shear strength failure mode by type of wood based materials were analyzed. The failure mode showed shear parallel-to-grain for glulam, rolling shear for CLT, and shear parallel-to-grain and rolling for ply-lam CLT. This is closely related to shear strength results and is decided to indicate higher shear strength in Ply-lam CLT than in CLT due to rolling shear.
\end{abstract}

Keywords: Ply-lam CLT, CLT, plywood, shear strength, glulam

\section{INTRODUCTION}

Cross-laminated timber, CLT developed for the use of small diameter wood of the native land and low-quality timber is a building material that was newly developed in Austria, Germany, and so on, Europe in the early of 1990(Chang et al., 2017; Karacabeyli et al., 2013; Song et al., 2016; Jeong et al., 2016). It is a glued laminated board that is bonded and processed by cross-laminating laminated boards and it is used for various structures such as shear walls, floors, and so on(Choi et al., 2018; Park et al., 2017; Oh et

\footnotetext{
${ }^{1}$ Date Received August 2, 2020, Date Accepted October 13, 2020

${ }^{2}$ Department of Bio-based materials, Chungnam National University, Deajeon 34134, Republic of Korea

${ }^{3}$ Huin co., Ltd. Gwangju 62235, Republic of Korea

† Corresponding author: Seog Goo KANG (e-mail: lachesis@cnu.ac.kr, ORCID: 0000-0002-2440-7070)
} 
al., 2017). Since uniformity of the materials is secured and there are only a few flaws of dry shrinkage and torsion, CLT has advantages to make quantitative structural calculation possible (Park et al., 2019). Because of such advantages of it, it has been used in grand scale, grand area, multi-floor structures in Europe, North America, and so on (Barker et al., 2014).

In the meantime, product quality standards regarding CLT are crucial in order for it to be used in grand-scale wooden buildings and thus CLT standards of EN 16351 were established in 2008, in Europe (Brandner et al., 2016). Hereafter, the criteria about CLT standards and the definition were provided in the countries such as America, Japan, and so on. The definition of ANSI/APA PRG 320(2019) that is America CLT standards is cited as engineered lumber that is cross-laminated with sawing lumber or structural composite lumber with more than 3 floors. A study about CLT that is hybrid-laminated with Laminated Veneer Lumber (LVL), Laminated Strand Lumber (LSL) among Structural composite lumber (SCL) has been processed (Wang et al., 2017; Davids et al., 2017; Nurdiansyah et al., 2020). The advantages of hybrid CLT mixed laminated with LVL, LSL are homogeneity and raw material transference rate. In block shear strength order : CLT, LVL, blended lamination, CLT, glued laminated timber, (CLT:3.2-3.8 MPa, LVL blended lamination CLT:7.7MPa, larch glued laminated timber:10.25 MPa), which showed high block shear strength. There has been a study of adhesive strength improvement between layers in the case that LVL is blend laminated among types of SCL as layered material of CLT (Zhao et al. 2015; Gong et al., 2016; Wang et al., 2017). In the case that CLT as a floor member that supports horizontal load is used for structural member used in a building, interlayer adhesion degradation results in the destruction of materials and eventually leads to the collapse of buildings. Thus, block shear strength is an important factor to secure a uniform adhesion.

Besides of overseas research trends, the study of strength characteristics and acoustic characteristics is underway in South Korea as a result of development of CLT cross-laminated with larch lamina laminate (Oh, 2018; Jang et al., 2019; Kang et al., 2019). In addition to the existing structural glued laminated, Ply-lam CLT blend-laminated with structural plywood was developed in 2015 year. Since then, the research on strength, insulation and building energy has been carried out (Choi et al., 2015; Choi et al., 2018; Chang et al., 2019; Chang et al., 2020).

In this research, the lamina of Ply-lam CLT, the configuration and use of plywood and the block shear strength according to the adhesive are evaluated. The optimal manufacture condition of Ply-lam CLT is thoroughly researched through comparison with the glued laminated timber and CLT mainly used in the wood structure construction as an engineered lumber.

\section{MATERIALS and METHODS}

\subsection{Testing materials}

\subsubsection{Lamination}

Laminations used in this research are larch (Larix kaempferi) which are used as structural lumber in the country and Douglas fir (Pseudotsuga menziesii) used in the manufacture of CLT abroad as comparison groups. The thickness of the lamination used was $10 \mathrm{~mm}$, and the moisture content was adjusted to $11 \pm 0.9 \%$. Also, over-dry specific gravity of larch was $0.51 \pm 0.19$ and that of Douglas fir was $0.52 \pm 0.23$ respectively.

\subsubsection{Plywood}

After considering industrialization of Ply-lam CLT, for the tree species of veneer, larch, pine (pinus densiflora, sieb, et, Zucc;pine), and tropical timber MLT 
Table 1. Plywood properties

\begin{tabular}{ccccc} 
Properties & $\begin{array}{c}\text { Oven-dry density } \\
\left.\text { (unit : } \mathrm{g} / \mathrm{cm}^{3}\right)\end{array}$ & $\begin{array}{c}\text { Moisture content } \\
\text { (unit : \%) }\end{array}$ & $\begin{array}{c}\text { Adhesive strength } \\
\text { (highly water-resistant } \\
\text { tensile-shear strength) } \\
\text { (unit : N/mm })\end{array}$ & $\begin{array}{c}\text { Formaldehyde } \\
\text { Emission } \\
\text { (unit : mg/L) }\end{array}$ \\
\hline $\begin{array}{c}\text { Larix kaempferi } \\
\text { pinus densiflora, } \\
\text { sieb, et, Zucc } \\
\quad \text { Hardwood } \\
\text { (Mixed Light }\end{array}$ & $0.5 \pm 0.02$ & $8.9 \pm 0.5$ & $0.92 \pm 0.14$ & $0.1\left(\mathrm{SE}_{0}\right)$ \\
Hardwood) & $0.49 \pm 0.01$ & $9.3 \pm 0.2$ & $1.07 \pm 0.24$ & $0.19\left(\mathrm{SE}_{0}\right)$ \\
\hline
\end{tabular}

(Mixed light hardwood) were selected among tree species that facilitates domestic supply and used. The veneer used was supplied from $\mathrm{S}$ company located in In-cheon. Water soluble alkaline phenolic resin (Solid content $47.7 \%$, pH 11.5) was used as adhesive for the manufacture of structural plywood, and calcium carbonate was used as hardener. This time, manufacture condition of plywood was that cross section application volume was $150 \mathrm{~g} / \mathrm{m}^{2}$, and hardener was mixed with $3 \%$ solid content of phenol resin, went through 7-minute-long $(40 \mathrm{sec} / \mathrm{mm})$ heat pressure process in the degree of $135^{\circ} \mathrm{C}$ and 24-hour cold pressure process, and was used as tasting materials of this research(Ko et al., 2015). The standard of manufactured plywood is $10(\mathrm{~T}) \times 400(\mathrm{~W}) \times 400(\mathrm{~L}) \mathrm{mm}$ and 5 ply plywood was manufactured. A basic property of matter of the used plywood is as shown in Table 1.

\subsubsection{Adhesive}

Room-temperature setting adhesive, phenol-resorcinol-formaldehyde resin (PRF, D-40, Oshika corporation, Japan), which is used in the manufacture of glued laminated timber to glue lamina to lamina, lamina to plywood and moisture curing type, polyvinyl acetate (PVAc, MPU 500, Okong Co., Ltd, Republic of Korea) with no formaldehyde emission were used as comparison groups.
PRF was added with powder-type Para-formaldehyde curing agent in the amount of 5\% based on the standard of solid content and PVAc adhesive was added with isocyanate curing agent with the ratio of the main material (100) : hardener (15).

\subsubsection{Manufacture of block shear test piece based on the condition}

2 test pieces of 2 ply in the size of 20 (T) $\times 200$ (W) $\times 400$ (T) $\mathrm{mm}$ were manufactured based on glued laminated timber as engineered lumber, CLT, composition and layered materials of Ply-lam CLT, tree species of plywood, types of adhesive, and the combination with layered materials and plywood. For block shear strength, or interlayer adhesion of manufactured test pieces to be tested, specimens were cut under the condition as shown in Table 2 and 10 per 1 test piece were collected, which was 20 in total. Adhesion method of glued laminated timber, the existing structural lumber is marked as Type 1, which makes layered material run parallel to the grain of wood and is glued to it. And adhesion method of CLT that glues the layered material to the grain of wood perpendicularly is marked as Type 2. Besides, adhesion method of Ply-lam CLT which makes lamina run parallel to plywood and is glued to it is marked as Type 3. To manufacture specimens for block shear test, layered material 
Gyu Woong CHOI $\cdot$ Seung Min YANG $\cdot$ Hyun Jae LEE $\cdot$ Jun Ho KIM $\cdot$ Kwang Hyeon CHOI $\cdot$ Seog Goo KANG

Table 2. Specimen type

\begin{tabular}{|c|c|c|c|c|c|c|}
\hline \multirow{2}{*}{ Specimen type } & \multicolumn{3}{|c|}{ Species } & \multirow{2}{*}{ Adhesive } & \multirow{2}{*}{ Repetition } & \multirow{2}{*}{$\begin{array}{l}\text { Specimen size of block } \\
\text { shear strength }\end{array}$} \\
\hline & Lamina & Lamina & Plywood & & & \\
\hline \multirow[t]{4}{*}{ Type 1} & Larch & Larch & \multirow{4}{*}{ - } & \multirow[b]{2}{*}{ PRF } & \multirow{20}{*}{20} & \multirow{20}{*}{ 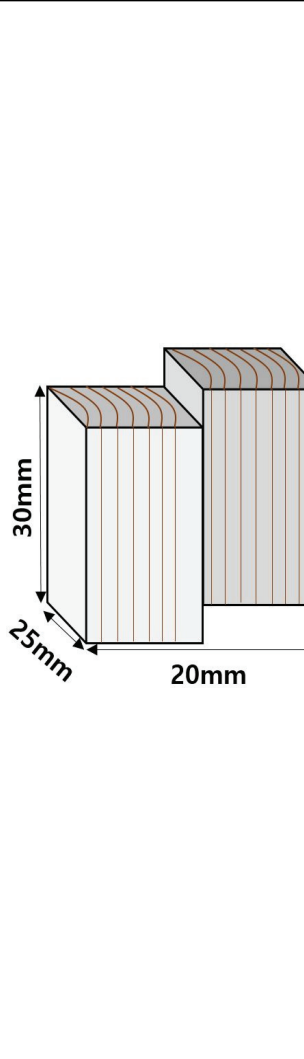 } \\
\hline & $\begin{array}{l}\text { Douglas } \\
\text { fir }\end{array}$ & $\begin{array}{l}\text { Douglas } \\
\text { fir }\end{array}$ & & & & \\
\hline & Larch & Larch & & \multirow[b]{2}{*}{ PVAc } & & \\
\hline & $\begin{array}{l}\text { Douglas } \\
\text { fir }\end{array}$ & $\begin{array}{c}\text { Douglas } \\
\text { fir }\end{array}$ & & & & \\
\hline \multirow[t]{4}{*}{ Type 2} & Larch & Larch & \multirow{4}{*}{-} & \multirow[b]{2}{*}{ PRF } & & \\
\hline & $\begin{array}{l}\text { Douglas } \\
\text { fir }\end{array}$ & $\begin{array}{l}\text { Douglas } \\
\text { fir }\end{array}$ & & & & \\
\hline & Larch & Larch & & \multirow[b]{2}{*}{ PVAc } & & \\
\hline & $\begin{array}{l}\text { Douglas } \\
\text { fir }\end{array}$ & $\begin{array}{l}\text { Douglas } \\
\text { fir }\end{array}$ & & & & \\
\hline \multirow{12}{*}{ Type 3} & \multirow{3}{*}{ Larch } & \multirow{12}{*}{ - } & Larch & \multirow{6}{*}{ PRF } & & \\
\hline & & & Pine & & & \\
\hline & & & Hardwood & & & \\
\hline & \multirow{3}{*}{$\begin{array}{l}\text { Douglas } \\
\text { fir }\end{array}$} & & Larch & & & \\
\hline & & & Pine & & & \\
\hline & & & Hardwood & & & \\
\hline & & & Larch & & & \\
\hline & Larch & & Pine & & & \\
\hline & & & Hardwood & DYA & & \\
\hline & & & Larch & PVAC & & \\
\hline & $\begin{array}{l}\text { Douglas } \\
\text { fir }\end{array}$ & & Pine & & & \\
\hline & & & Hardwood & & & \\
\hline
\end{tabular}

in the size of $10(\mathrm{~T}) \times 300(\mathrm{~W}) \times 300(\mathrm{~L}) \mathrm{mm}$ was combined and glued with plywood. And it was applied with adhesive on the standard of cross section application volume, $150 \mathrm{~g} / \mathrm{m}^{2}$ and was cold-pressured for 24 hours in pressure conditions of $0.98 \mathrm{MPa}$, then was cooled off for 7 days, and the specimens were cut and used.

\subsection{Test method}

\subsubsection{Analysis of strength and failure mode}

For the strength evaluation, block shear test was carried out in accordance with the standards of struc- tural glued laminated timber, KS F 3021 standards of glued laminated timber. Block shear specimen was measured by setting the load speed to $2 \mathrm{~mm} / \mathrm{min}$ using the universal testing machine (KDPI-130-1). Using the value of the maximum load and adhesive area at the time of destruction, it was calculated in accordance with the e.q. (1).

$$
\begin{aligned}
& \text { shearstrength }\left(\mathrm{N} / \mathrm{mm}^{2}\right)=\frac{P_{\max }}{A} \\
& P_{\max }: \operatorname{maximumload}(N) \\
& A: \text { sheararea }\left(\mathrm{mm}^{2}\right)
\end{aligned}
$$


With the calculated results, a one-batch dispersion analysis (One-way ANOVA) was implemented using SPSS (ver. 24.0, SPSS Inc., USA) and significance $(P<0.05)$ of the average value was confirmed with Duncan's multiple range test.

The wood destruction rate according to the block shear strength test was calculated according to ASTM D 5266-99 by applying the $0.5 \mathrm{~mm}$ lattice on the shear surface of the specimen and measuring it. And the destruction pattern of the adhesive cross-section by the compression force using the destroyed specimen was analyzed.

\section{RESULTS and DISCUSSION}

In this research, through analysis of block shear strength according to layered material of Ply-lam CLT, composition of plywood, tree species used, and adhesive and comparing with glued laminated timber and CLT, there has been an attempt to study optimal manufacture condition of Ply-lam CLT.

\subsection{Types of adhesion and comparison of block shear strength according to adhesive}

In the case of using PRF adhesive, the results of shear strength according to the wood material type is the same as Table 3. As a result, in the order of Type 1 (glued laminated timber) $>$ type 3 (Ply-lam CLT) $>$ type 2 (CLT), a high shear strength was shown. It was found to show a significant difference depending on the adhesion methods, tree species and the wood material type ( $p=0.000$ ) as a result of the significant verification results. There was no significant difference between the species of Type 1 and Type 2 . In the case of Type 3, different results were found depending on the combination of layered materials and plywood. High shear strength was verified when making such configuration as larch plywood and Douglas fir layered material $(8.1 \pm 0.5 \mathrm{MPa})$, the pine plywood and Douglas fir layered material $(6.3 \pm 1.0 \mathrm{MPa})$, and tropical lumber plywood and larch layered material $(7.7 \pm 1.2 \mathrm{MPa})$.

Table 3. Results of block shear strength and Wood Failure using PRF adhesive

\begin{tabular}{|c|c|c|c|c|c|c|}
\hline \multirow{2}{*}{ Specimen type } & \multicolumn{3}{|c|}{ Species } & \multirow{2}{*}{ Adhesive } & \multirow{2}{*}{$\begin{array}{c}\text { Block Shear strength } \\
\quad \text { (unit : } \mathrm{MPa} \text { ) } \\
\mathrm{F}=34.258^{* *}\end{array}$} & \multirow{2}{*}{$\begin{array}{l}\text { Wood Failure } \\
\text { (unit : \%) }\end{array}$} \\
\hline & Lamina & Lamina & Plywood & & & \\
\hline \multirow[t]{2}{*}{ Type 1} & Larch & Larch & \multirow{2}{*}{ - } & \multirow{10}{*}{ PRF } & $11.0 \pm 0.7^{\mathrm{a}}$ & 99.7 \\
\hline & Douglas fir & Douglas fir & & & $10.7 \pm 0.4^{\mathrm{a}}$ & 97.8 \\
\hline \multirow[t]{2}{*}{ Type 2} & Larch & Larch & & & $3.6 \pm 0.8^{\mathrm{e}}$ & 99.3 \\
\hline & Douglas fir & Douglas fir & & & $4.3 \pm 1.0^{\mathrm{de}}$ & 99.0 \\
\hline \multirow{6}{*}{$\begin{array}{l}\text { Type } 3 \\
\text { Plywood } \\
\text { Nan }\end{array}$} & \multirow{3}{*}{ Larch } & \multirow{6}{*}{-} & Larch & & $7.7 \pm 0.7^{\mathrm{b}}$ & 99.4 \\
\hline & & & Pine & & $6.0 \pm 0.9^{\mathrm{c}}$ & 98.9 \\
\hline & & & Hardwood & & $7.7 \pm 1.2^{\mathrm{b}}$ & 99.1 \\
\hline & \multirow{3}{*}{ Douglas fir } & & Larch & & $8.1 \pm 0.5^{\mathrm{b}}$ & 99.5 \\
\hline & & & Pine & & $6.3 \pm 1.0^{\mathrm{c}}$ & 98.4 \\
\hline & & & Hardwood & & $5.5 \pm 0.9^{\mathrm{cd}}$ & 99.0 \\
\hline
\end{tabular}

The data are expressed as the mean $\pm \mathrm{SD}(\mathrm{n}=20)$. Mean separation within columns by Duncan's new multiple range test. Mean with rows with different superscripts are significantly different $(p<0.05)$. 
Gyu Woong CHOI $\cdot$ Seung Min YANG $\cdot$ Hyun Jae LEE $\cdot$ Jun Ho KIM $\cdot$ Kwang Hyeon CHOI $\cdot$ Seog Goo KANG

Table 4. Results of block shear strength and Wood Failure using PVAc adhesive

\begin{tabular}{|c|c|c|c|c|c|c|}
\hline \multirow{2}{*}{$\begin{array}{l}\text { Specimen } \\
\text { type }\end{array}$} & \multicolumn{3}{|c|}{ Species } & \multirow{2}{*}{ Adhesive } & \multirow{2}{*}{$\begin{array}{c}\text { Block Shear strength } \\
\text { (unit : MPa) } \\
\mathrm{F}=75.519^{* *}\end{array}$} & \multirow{2}{*}{$\begin{array}{c}\text { Wood Failure } \\
\text { (unit : \%) }\end{array}$} \\
\hline & Lamina & Lamina & Plywood & & & \\
\hline \multirow{2}{*}{ Type 1} & Larch & Larch & \multirow{2}{*}{ - } & \multirow{10}{*}{ PVAc } & $11.8 \pm 0.4^{\mathrm{b}}$ & 99.6 \\
\hline & Douglas fir & Douglas fir & & & $13.6 \pm 1.0^{\mathrm{a}}$ & 99.8 \\
\hline \multirow[t]{2}{*}{ Type 2} & Larch & Larch & \multirow{2}{*}{-} & & $5.6 \pm 0.2^{\mathrm{d}}$ & 98.9 \\
\hline & Douglas fir & Douglas fir & & & $3.5 \pm 0.6^{\mathrm{e}}$ & 98.4 \\
\hline \multirow{3}{*}{ Type 3} & \multirow{3}{*}{ Larch } & \multirow{6}{*}{-} & Larch & & $8.7 \pm 1.0^{\mathrm{c}}$ & 99.1 \\
\hline & & & Pine & & $6.0 \pm 0.8^{\mathrm{d}}$ & 98.9 \\
\hline & & & Hardwood & & $5.8 \pm 0.5^{\mathrm{d}}$ & 98.7 \\
\hline \multirow{3}{*}{ 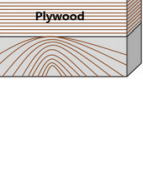 } & \multirow{3}{*}{ Douglas fir } & & Larch & & $6.7 \pm 1.2^{\mathrm{d}}$ & 99.1 \\
\hline & & & Pine & & $5.9 \pm 0.4^{\mathrm{d}}$ & 98.6 \\
\hline & & & Hardwood & & $5.5 \pm 0.5^{\mathrm{d}}$ & 98.4 \\
\hline
\end{tabular}

The data are expressed as the mean $\pm \mathrm{SD}(\mathrm{n}=20)$. Mean separation within columns by Duncan's new multiple range test. Mean with rows with different superscripts are significantly different $(p<0.05)$.

Table. 5. Results of adhesive type and specimen type

$\left(\mathrm{F}=80.846^{* *}\right)$

\begin{tabular}{|c|c|c|c|c|}
\hline Adhesive & Specimen type & Type 1 & Type 2 & Type 3 \\
\hline & PRF & $12.7 \pm 1.3^{\mathrm{a}}$ & $4.6 \pm 1.2^{\mathrm{d}}$ & $6.5 \pm 1.4^{\mathrm{c}}$ \\
\hline & PVAc & $10.9 \pm 0.6^{\mathrm{b}}$ & $4.0 \pm 1.0^{\mathrm{d}}$ & $6.8 \pm 1.4^{\mathrm{c}}$ \\
\hline
\end{tabular}

The data are expressed as the mean $\pm \operatorname{SD}(n=40)$. Mean separation within columns by Duncan's new multiple range test. Mean with rows with different superscripts are significantly different $(p<0.05)$.

In the case of using PVAc adhesive, the results of shear strength according to the wood material type is the same as Table 4. High shear strength was shown in the order of Type $1>$ Type $3>$ Type 2 as a result of using the PRF adhesive. It was found to show a significant difference depending on the adhesion methods, tree species and the wood material type $(p=$ 0.000 ) as a result of the significant verification results. There was significant difference between the species of Type 1 and Type 2 .

Douglas fir in Type 1 and larch in Type 2 had higher results. In the case of Type 3 , it showed a higher block shear strength when using larch as a layered material, and in the order of larch plywood (8.7 \pm 1.0 $\mathrm{MPa})$, pine plywood $(6.0 \pm 0.8 \mathrm{MPa})$, tropical lumber plywood $(5.8 \pm 0.5 \mathrm{MPa})$, high shear strength was shown.

Significance verification results of the adhesive type and wood material type is shown as Table 5 and showed a significant difference among the wood material types $(p=0.000)$. In Type 1 , block shear strength was found higher when using PRF adhesive than when using PVAc adhesive, but in Type 2 and Type 3, significant difference was not found according to the ad- 
hesive type.

As a result of the block shear strength and wood destruction rate according to the wood material type, Type 1 showed $11.8 \pm 1.3 \mathrm{MPa}, 99.2 \%$, Type 2 showed $4.3 \pm 1.1 \mathrm{MPa}, 98.9 \%$, and Type 3 showed results of 6.7 $\pm 1.4 \mathrm{MPa}, 98.9 \%$. In Type 1 as structural glued laminated timber, shear strength in the domestic standard, KS F 3021 is stated as more than $7.1 \mathrm{MPa}$, the wood destruction rate is stated as $65 \%$, and in the European standard EN 14080, shear strength is stated as 6.0 $\mathrm{MPa}$ or more, and the wood destruction rate as $90 \%$. CLT interlayer adhesion method of Type 2 is not provided with domestic standards and is specified as 1 MPa of shear strength in the European EN 16351 standard. Ply-lam CLT product standard of Type 3 is also not established. And comparing shear strength was attempted based on the standards of glued laminated timber and CLT. Shear strength of Type 3 showed an average of $6.7 \pm 1.4 \mathrm{MPa}$. When laminating larch lamina with plywood, the shear strength passes European standard (6.0 MPa or more) and the domestic glued laminated timber standard (7.1 MPa or more) although there are conditions that do not meet the standards. It is understood that higher shear strength was realized by laminating the surface veneer of plywood and the layered material parallel to the grain of wood. Ply-lam CLT has a higher shear strength than the existing CLT when laminated with larch layered material and plywood, which can ensure the shear strength to the level of glued laminated timber.

\subsection{Block shear strength failure mode according to types of wood material}

After the test of block shear strength, failure mode analysis was processed and PRF adhesive was applied as shown in Table 6, PVAc adhesive in Table 7. Types of adhesive didn't make much difference and shear parallel-to-grain was found in Type 1, rolling shear in Type 2, shear parallel-to-grain and rolling shear in
Type 3 compositely. Type 3 is made of $6 \%$ of destruction of stratum and $94 \%$ of plywood destruction. Destruction by rolling shear in the single plate of the second layer mainly perpendicular to fiber instead of surface layer single plate of plywood.

Decrease factor of shear strength value through failure mode of adhesive surface is related to formation stratum, single plate thickness of plywood, and rolling shear. It was reported that the thinker formation stratum of CLT and CLT thickness get, the more rolling shear strength decreases (Sikora et al., 2016.)

Through this research, it was attempted to study thoroughly the optimal manufacture condition in regard with Ply-lam CLT. On passing shear performance criteria for structural glued-laminated timber, 7.1 MPa, the condition of larch layered material-larch plywood, larch layered material-tropical lumber plywood, and Douglas fir layered material- larch plywood using PRF adhesive was drawn. As a result of wood shear rate by over $95 \%$ of Ply-lam CLT, $150 \mathrm{~g} / \mathrm{m}^{2}$ of application volume is understood to be the optical condition.

It is understood that according to thickness of single plate plywood, tree species, etc, additional research regarding rolling shear performance of plywood is necessary in an attempt to prevent rolling shear that occurs in the middle layer of plywood for improving block shear strength of Ply-lam CLT.

\section{CONCLUSION}

In this research, strength and fracture types were compared and analyzed by implementing block shear testing of glued laminated timber as engineered lumber, which is mainly used in wood structural architecture, CLT, and Ply-lam CLT. Through this, the condition of manufacture for lamina of Ply-lam CLT, species of woods, types of adhesive, layer composition, and so on was thoroughly studied for optimal production, whose results are as follows. 
Gyu Woong CHOI $\cdot$ Seung Min YANG $\cdot$ Hyun Jae LEE $\cdot$ Jun Ho KIM $\cdot$ Kwang Hyeon CHOI $\cdot$ Seog Goo KANG

Table 6. Failure mode of Specimen type using PRF resin
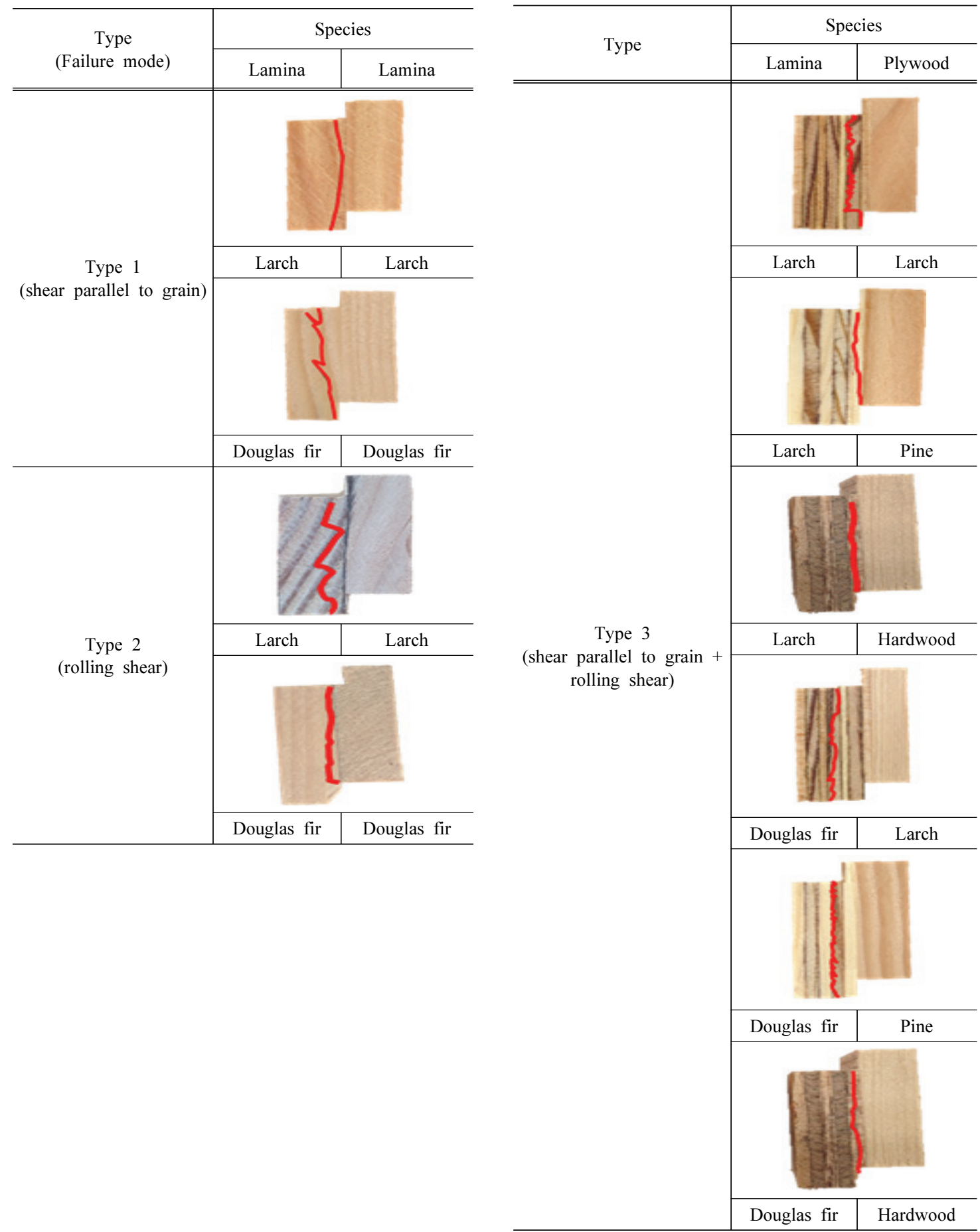
A Study on the Block Shear Strength according to the Layer Composition of and Adhesive Type of Ply-Lam CLT

Table 7. Failure mode of Specimen type using PVAc resin
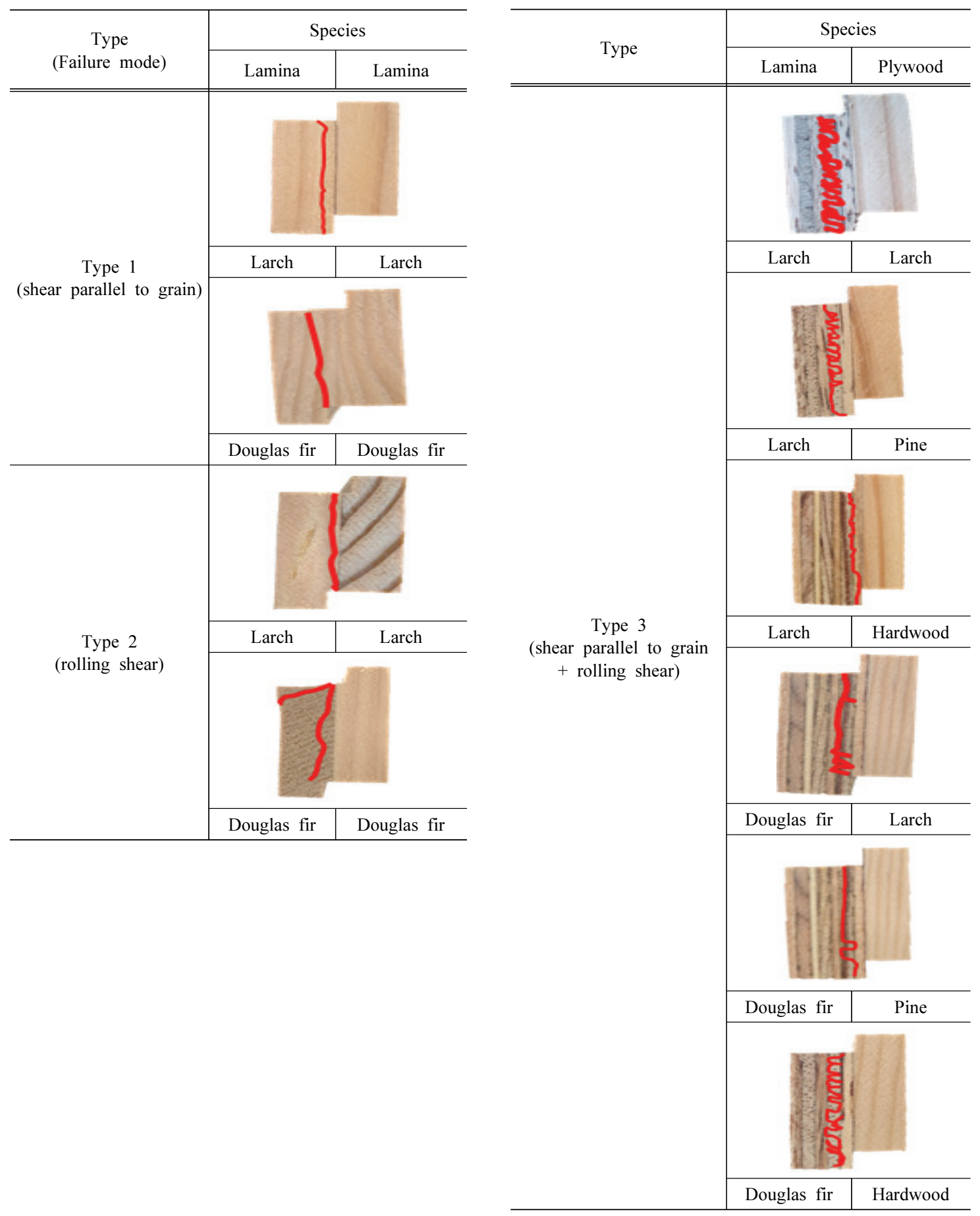
Gyu Woong CHOI $\cdot$ Seung Min YANG $\cdot$ Hyun Jae LEE $\cdot$ Jun Ho KIM $\cdot$ Kwang Hyeon CHOI $\cdot$ Seog Goo KANG

1. Glued laminated timber came to be the first, Ply-lam CLT the second, and CLT the third in the order of high strength and the shear strength of Ply-lam CLT manufactured as complex structure of larch plywood and larch lamina passed the standard of shear strength of glued laminated timber, $7.1 \mathrm{~N} / \mathrm{mm}^{2}$ during configuration of Plylam CLT. Whereas differences were made based on the types of wood material, those were not noticeable based on the types of interlayer adhesive of Ply-lam CLT. Using larch layered material and larch plywood, and tropical lumber plywood came to be the optimal manufacture condition of Ply-lam CLT and it was appropriate to use adhesive such as PRF, or PVAc in the application volume of $150 \mathrm{~g} / \mathrm{m}^{2}$ according to purpose of use.

2. By means of the analysis of shear strength failure mode according to types of wood material, it was confirmed that shear parallel-to-grain was found in glued laminated timber, rolling shear was found in CLT, and shear parallel-to-grain and rolling shear appeared compositely in CLT. It is understood that higher shear strength is shown in Ply-lam CLT than in CLT due to rolling shear due to the decrease of rolling strength of Type 2 as a result of differences in the thickness of single plate and vertical laminated layer material.

3. It is understood that additional research is necessary to improve rolling shear of plywood, singleplate thickness, tree species, etc in an attempt to prevent rolling shear that occurs in the middle layer of plywood for improving block shear strength of Ply-lam CLT to be higher than that of the existing CLT.

\section{ACKNOWLEDGMENT}

This study was carried out with the support of 'R\&D
Program for Forest Science Technology (Project No. 2020161C10-2020-AD01)' provided by Korea Forest Service (Korea Forestry Promotion Institute).

\section{REFERENCES}

American Society for Testing and Materials (ASTM). 2005. D5266-99. Standard practice for estimating the percentage of wood failure in adhesive bonded joints.

ANSI/APA PRG 320 Standard for performance-rated cross-laminated timber. 2019. The Engineered Wood Association.

Baker, W.F., Horos, D.R., Johnson, B.M., Schultz, J.A. 2014. Timber tower research: Concrete jointed timber frame. Proceedings of the Structures Congress. USA. pp. 1255-1266.

Blass, H.J., Gorlacher, R. 2000. Rolling shear in structural bonded timber elements. Proceeding of International Conferences on Wood and Wood Fiber Composites. Stuttgart, Germany. pp. 327-337.

Brandiner, R., Flatscher, G., Ringhofer, A., Schickhofer, G., Thiel, A. 2016. Cross laminated timber (CLT): Overview and development. European Journal of Wood and Wood Products 74: 331-351.

Chang, S.J., Wi, S.H., Lee, J.K., Lee, H.Y., Cho, H.M., Kim, S.M. 2017. Analysis of cooling and heating energy demands of wooden houses with crosslaminated timber (CLT) using domestic plywood as core materials. Journal of the Korean Society of Living Environmental System 24(6): 752-759.

Chang, S.J., Wi, S.H., Kim, S.M. 2019. Thermal Bridging analysis of connections in cross laminated timber building based on ISO 10211. Construction and Building Materials 213: 709-722.

Chang, S.J., Wi, S.H., Kang, S.G., Kim, S.M. 2020. Moisture risk assessment of cross laminated timber walls: Perspectives on climate conditions and water vapor resistance performance of building materials. 
A Study on the Block Shear Strength according to the Layer Composition of and Adhesive Type of Ply-Lam CLT

Building and Environment 168: 1-11.

Choi, C., Yuk, C.R., Yoo, J.C., Park, J.Y., Lee, C.G., Kang, S.G. 2015. Physical and mechanical properties of cross laminated timber using plywood as core layer. Journal of the Korean Wood Science and Technology 43(1): 86-95.

Choi, C., Kojima, E., Kim, K.J., Yamasaki, M., Sasaki, Y., Kang, S.G. 2018. Analysis of mechanical properties of cross-laminated timber (CLT) with plywood using Korean larch. BioResources 13(2): 2715-2726.

Choi, Y.S., Park, J.W., Lee, J.H., Shin, J.H., Jang, S.W., Kim, H.J. 2018. Preparation of EVA/Instumescent/ Nano-Clay composite with flame retardant properties and cross laminated timber (CLT) application technology. Journal of the Korean Wood Science and Technology 46(1): 73-84.

Davids., W.G., Willey, N., Roberto, L.A., Shaler, S., Gardner, D., Edgar, R., Tajvidi, M. 2017. Structural performance of hybrid SPFs-LSL cross-laminated timber panels. Construction and Building Materials 149: $156-163$.

European Committee for standardization. 2014. EN 16351. Timber structures-cross laminated timberrequirements.

Gong, Y., Wu, G., Ren, H. 2016. Block shear strength and delamination and cross laminated timber fabricated with japanese larch. Bioresources 11(4): 10240-10250.

Jeong, G.Y., Lee, J.J., Yeo, H.M., Lee, S.S. 2016. Prediction lamina yield from logs of different diameters for cross laminted timber production. Journal of the Korean Wood Science and Technology 44(6): 809-820.

Jang, S.S., Lee, H.W. 2019. Lateral resistance of CLT wall panels composed of squre timber larch core and plywood cross bands. Journal of the Korean Wood Science and Technology 47(5): 547-556.

Karacabeyli, E., Douglas, B. 2013. CLT handbook-US ed. FPInnovations Special Publication SP-529E. Kang, C.W., Jang, S.S., Kang, H.Y., Li, C. 2019. Sound absorption rate and sound transmission loss of CLT wall panels composed larch square timber core and plywood cross band. Journal of the Korean Wood Science and Technology 47(1): 33-39.

Ko, J.H., Roh, J.K. 2015. Utilization of waste bone powders as adhesive fillers for plywood. Journal of the Korean Wood Science and Technology 43(4): 528-537.

Korean Standard. 2018. KS F 3021. Structural glued laminated timber.

Nurdiansyah, M.G., Yang, S.M., Yu, S.M., Kang, S.G. 2020. Study on the mechanical properties of tropical hybrid cross laminated timber using bamboo laminated board as core layer. Journal of the Korean Wood Science and Technology 48(2): 245-252.

Oh, J.K., Kim, G.C., Kim, K.M., Lee, J.J., Hong, J.P. 2017. End distance of single-shear screw connection in cross laminated timber. Journal of the Korean Wood Science and Technology 45(6): 746-752.

Oh, S.C. 2018. Planar (Rolling) shear strength of structural panels using 5-point bending test. Journal of the Korean Wood Science and Technology 46(5): 425-436.

Park, S.H., Kim, K.M., Pang, S.J., Kong, J.H., Lee, S.J. 2017. Evaluation of shear strength by direction of wood grain for Korean pine using PRF adhesive. Journal of the Korean Wood Science and Technology 45(3): 243-249.

Park, A.R., Lee, K.H. 2019. Experimental and analytical study of shear connectors for the CLT- Concrete composite floor system. Journal of Korean Association for Spatial Structures 19(1): 65-73.

Sikora, K.S., McPolin, D.O., Harte, A.M. 2016. Effects of the thickness of cross-laminated timber (CLT) panels made from Irish Sitka Spruce on mechanical performance in bending and shear. Construction and Building Materials 116: 141-150. 
Gyu Woong CHOI $\cdot$ Seung Min YANG $\cdot$ Hyun Jae LEE $\cdot$ Jun Ho KIM $\cdot$ Kwang Hyeon CHOI $\cdot$ Seog Goo KANG

Song, Y.J. Hong, S.I. 2016. Evaluation of bending strength of larch cross-laminated timber. Journal of the Korean Wood Science and Technology 44(4): 607-615.

Wang, Z., Fu, H., Gong, M., Luo, J., Dong, W., Wang, T., Chui, Y.H. 2017. Planar shear and bending properties of hybrid CLT fabricated with lumber and LVL. Construction and Building Materials 151: 172-177.

Zhao, L., Shen, S.J., Li, J. 2015. Study on gluing property to structural glulam with different types of adhesive and timber. China Forest Products Industry 42(11): 39-45. 


\title{
APPENDIX
}

\author{
(Korean Version)
}

\section{Ply-Lam CLT의 층재 구성 및 접착제 종류에 따른 블록전단강도에 관한 연구}

초록 : 본 연구에서는 공학목재로 목구조건축에 주로 사용되는 집성재 및 CLT 그리고 Ply-lam CLT의 블록전단시험을 실시하여 강도 및 파괴 유형을 비교 분석하였다. 이를 통해 Ply-lam CLT의 라미나 및 합판의 수종, 접착제의 종류 및 Layer구성 등 최적생산을 위한 제조조건을 구명하고자 하였으며 그 결과는 다음과 같다. 블록전단시험을 통해 집성재, Ply-lam CLT, CLT 순으로 높은 강도를 나타냈다. 특히, 낙엽송 합판과 낙엽송 라미나의 복합구조로 제조되는 Ply-lam CLT의 전단강도는 집성재 전단강도 기준인 $7.1 \mathrm{~N} / \mathrm{mm}^{2}$ 을 통과하였다. 아울러 본 연구에서는 집성재, CLT, Ply-lam 접착에 사용된 접착제 종류에 따른 전단강도의 차이는 나타나지 않았다. 그러나 Ply-lam CLT의 경우에는 라미나와 합판의 수종에 따라 Ply-lam CLT의 전단강도의 차이를 나타냈다. 그 결과는 낙엽송 > 남양재 $\fallingdotseq$ 육송 합판 순으로 높은 강도를 나타났다. Ply-lam CLT의 최적 구성은 낙엽송 합판과 낙엽송 라미나를 사용하는 경우이며 접착제는 용도에 따라 PRF, PUR을 선정하여 사용하면 될 것으로 판단된다. 목질재료 유형에 따른 전단강도 파괴 양상 결과 분석을 통하여 집성재는 shear parallel-to-grain, CLT는 rolling shear, Ply-lam CLT는 shear parallel-to-grain과 rolling shear가 복합적으로 나타났다. 이는 전단강도 결과와 밀접한 관련이 있으며 rolling shear로 인하여 CLT보다 Ply-lam CLT에서 더 높은 전단 강도를 나타내는 것으로 판단된다.

\section{1. 서 론}

자국의 소경목 및 저급 목재의 사용을 위하여 개발된 구조용집성판(Cross-laminated timber; CLT)은 1990년대 초 유럽 오스트리아와 독일 등에서 개발된 새로운 건축재료이다(Chang et al., 2017; Karacabeyli et al., 2013; Song et al., 2016; Jeong et al., 2016). 이는 집성판을 교차 적층하여 접착 가공한 판상형 목재로 전단벽과 바닥 등의 다양한 구조로 사용된다(Choi, et al., 2018; Park et al., 2017; Oh et al., 2017). 구조용 집성판은 재료의 균일성 확보와 건조 수축 및 비틀림의 결함이 거의 없어 정량적인 구조계산이 가능하다는 장점이 있다(Park et al., 2019). 이러한 장점으로 유럽과 북미 등에서는 대규모·대공간다 층 구조에 널리 사용되고 있다(Barker et al., 2014).

한편 대형 목조 건물 등에 사용되기 위하여 구조용 집성판에 대한 제품 품질기준이 필수적이며 2008년 유럽에서는 $\mathrm{EN}$ 16351의 CLT 규격을 제정하였다(Brandner et al., 2016). 이후 미국, 일본 등의 국가에서 CLT 규격 및 정의에 대한 기준을 마련하였다. 미국 CLT 규격인 ANSI/APA PRG 320(2019)에 대한 정의는 제재목 또는 Structural composite lumber(이하 $\mathrm{SCL}$ )이 3층 이상 교차 적층된 공학목재라고 명시되어있다. SCL 중 Laminated Veneer Lumber(이하 LVL), Laminated Strand Lumber(이하 LSL) 등이 혼합 적층된 구조용집성판에 대한 연구가 진행되고 있다(Wang et al., 2017; Davids et al., 2017; Nurdiansyah et al., 2020). LVL, LSL 등을 혼합 적층한 Hybrid CLT는 균질성, 원재료 수율 향상 등의 장점이 있다. 또한 목질재료 유형에 따른 블록전단강도는 CLT, LVL 혼합적층 CLT, 집성재 순으로 높은 블록전단강도(CLT:3.2-3.8 MPa, LVL 혼합 적층 CLT:7.7MPa, 낙엽송 집성재:10.25 MPa)를 나타냈다. CLT의 층재로 SCL의 종류 중 LVL을 혼합 적층 시 층간 접착강도 향상에 대한 연구가 진행된 바 있다(Zhao et al. 2015; Gong, et al., 2016; Wang et al., 2017). 건축물 사용되는 구조부재에 CLT를 수평 하중을 받는 바닥부재로 사용될 경우 층간 접착력 저하는 재료의 파괴에서 건축물의 붕괴로 이어지므로 제품 블록전단강도는 균일한 접착력 확보를 위한 중요한 요소이다.

국외의 연구동향 뿐만 아니라 국내도 낙엽송 라미나 집성판을 교차 적층한 CLT 개발로 강도 특성 및 음향 특성에 대한 연구가 진행되고 있다(Oh, 2018; Jang et al., 2019; Kang et al., 2019). 기존 구조용집성판 뿐만 아니라 2015년 구조용 합판이 혼합 적층된 Ply-lam CLT가 개발되었으며 이후 강도, 단열 및 건물에너지 등에 대한 연구가 진행되고 있다(Choi et al., 2015; Choi et al., 2018; Chang et al., 2019; Chang et al., 2020).

본 연구에서는 Ply-lam CLT의 라미나, 합판의 구성과 사용수종 그리고 접착제에 따른 블록전단강도를 평가하고 공학목재로 서 목구조건축에 주로 사용되는 집성재 및 CLT와의 비교를 통하여 Ply-lam CLT 최적제조조건을 구명하고자 한다. 
Gyu Woong CHOI $\cdot$ Seung Min YANG $\cdot$ Hyun Jae LEE $\cdot$ Jun Ho KIM $\cdot$ Kwang Hyeon CHOI $\cdot$ Seog Goo KANG

\section{2. 재료 및 방법}

\section{1. 공시재료}

\subsection{1. 층재}

본 연구에 사용된 층재는 국내에서 구조용재로 많이 사용되고 있는 낙엽송(Larix kaempferi;이하 larch)과 국외 CLT 제조에 사용되는 미송(Pseudotsuga menziesii; 이하 Douglas fir)을 비교군으로 사용하였다. 이때 사용된 층재의 두께는 $10 \mathrm{~mm}$ 이었으며, 함수율은 $11 \pm 0.9 \%$ 로 조정하여 사용하였다. 또한, 전건 비중은 각각 낙엽송이 $0.51 \pm 0.19$, 미송의 경우 $0.52 \pm 0.23$ 이었다.

\subsection{2. 합판}

Ply-lam CLT의 산업화를 고려하여 단판의 수종은 국내 수급이 용이한 수종 중 낙엽송과 육송(pinus densiflora, sieb, et, Zucc;pine) 그리고 남양재 MLT(Mixed light hardwood) 수종의 3가지를 선정하여 사용하였다. 사용된 단판은 인천소재의 $\mathrm{S}$ 사로 부터 분양받았다. 구조용 합판제조에 사용된 접착제로는 수용성 알카리 페놀수지(고형분 함량 $47.7 \%, \mathrm{pH} 11.5$ )가 사용되었으며, 경화제로는 탄산칼슘을 사용하였다. 이때 합판의 제조조건은 단면 도포량 $150 \mathrm{~g} / \mathrm{m}^{2}$ 이며 경화제는 페놀수지 고형분 함량의 $3 \%$ 혼합하여 $135^{\circ} \mathrm{C}$ 에서 7 분 $(40 \mathrm{sec} / \mathrm{mm})$ 의 열압공정 후 24 시간의 냉압 공정을 통해 본 연구의 공시재료로 사용하였다(Ko, et al., 2015).

제조된 합판의 규격은 $10(\mathrm{~T}) \times 400(\mathrm{~W}) \times 400(\mathrm{~L}) \mathrm{mm}$ 로 $5 \mathrm{ply}$ 합판을 제조하였다. 사용된 합판의 기본 물성은 Table 1 과 같다.

\subsection{3. 접착제}

라미나와 라미나, 라미나와 합판의 접착을 위하여 집성목 제조 시 많이 사용되는 상온경화형 페놀-레조르시놀공축합수지 (Phenol-resorcinol-formaldehyde resin; 이하PRF, D-40, Oshika corporation, Japan)와 포름알데히드 발생량이 없는 습기경화형 초산비닐수지(Polyvinyl acetate 이하;PVAc, MPU 500, Okong Co., Ltd, Republic of Korea)를 비교군으로 사용하였다. PRF는 파우더형 파라포름알데히드 경화제를 고형분 함량 기준 $5 \%$ 첨가, PVAc 접착제는 이소시아네이트계 경화제를 주제(100):경화 제(15) 첨가하였다.

\subsection{4. 제조조건에 따른 블록전단 시험편 제조}

공학목재인 집성재, CLT와 Ply-lam CLT의 구성 및 층재, 합판의 수종과 접착제의 종류, 층재와 합판의 조합에 따라 $20(\mathrm{~T}) \times 200(\mathrm{~W}) \times 400(\mathrm{~T}) \mathrm{mm}$ 크기로 $2 \mathrm{ply}$ 시험편 2 장을 제조하였다. 제조된 시험편은 층간 접착력인 블록전단강도 평가를 위하여 Table 2 와 같은 조건으로 시편을 재단하였으며 1 장당 10 개씩 총 20 개 시험편을 채취하였다. 층재를 목리에 따라 평행 방향으로 접착하는 기존의 구조용재인 집성재의 접착방식을 Type 1 로 표기하고, 층재를 목리가 직교하도록 접착하는 CLT의 접착방식을 Type 2로 표기하였다. 또한, 라미나와 합판이 평행 방향으로 접착하는 Ply-lam CLT의 접착방식을 Type 3 로 표기하였다. 블록전단실험용 시편 제조를 위하여 $10(\mathrm{~T}) \times 300(\mathrm{~W}) \times 300(\mathrm{~L}) \mathrm{mm}$ 크기의 층재와 합판을 조합하여 접착하였으며 단면도포량 기준 $150 \mathrm{~g} / \mathrm{m}^{2}$ 으로 접착제 도포 후 $0.98 \mathrm{MPa}$ 의 압력 조건에서 24시간 냉압 후 7일간의 양생기간을 거쳐 시편을 재단하여 사용하였다.

\section{2. 실험방법}

2.2.1. 강도 평가 및 파괴양상 분석

강도 평가를 위하여 국내 집성재 규격인 KS F 3021 구조용집성재 기준에 따라 블록전단시험을 수행하였다. 블록전단시편은 만능재료시험기(KDPI-130-1)를 이용하였으며 하중속도는 $2 \mathrm{~mm} / \mathrm{min}$ 으로 설정하여 측정하였다. 파괴 시의 최대하중과 접착면 적의 값을 이용하여 e.q. (1)에 의거하여 산출하였다.

$$
\begin{aligned}
& \text { shear strength }\left(\mathrm{N} / \mathrm{mm}^{2}\right)=\frac{P_{\max }}{A} \\
& P_{\max }: \text { maximumload }(\mathrm{N}) \\
& A: \text { shear area }\left(\mathrm{mm}^{2}\right)
\end{aligned}
$$

산출된 결과는 SPSS(ver. 24.0, SPSS Inc., USA)를 이용하여 일원배치 분산분석(One-way ANOVA)을 실시하였으며 평균값 의 유의성 $(p<0.05)$ 은 Duncan`s multiple range test로 검정하였다.

블록전단강도시험에 따른 목파율은 시험편의 전단면에 $0.5 \mathrm{~mm}$ 격자를 적용 및 측정하여 ASTM D 5266-99에 따라 산출하였 
A Study on the Block Shear Strength according to the Layer Composition of and Adhesive Type of Ply-Lam CLT

으며 파괴된 시험편을 이용하여 압축력에 의한 접착단면의 파괴양상을 분석하였다.

\section{3. 결과 및 고찰}

본 연구에서는 Ply-lam CLT의 층재, 합판의 구성과 사용수종 그리고 접착제에 따른 블록전단강도를 평가하고 공학목재로써 목구조건축에 주로 사용되는 집성재 및 CLT와의 비교를 통하여 Ply-lam CLT 최적제조조건을 구명하고자하였다.

3.1. 접착방식 및 접착제에 따른 전단강도 비교

$\mathrm{PRF}$ 접착제를 사용한 경우 목질재료유형에 따른 전단강도 결과는 Table 3과 같다. 그 결과 Type 1 (집성재) > Type 3 (Ply-lam CLT) > Type 2 (CLT)의 유형 순서대로 높은 전단강도를 나타냈다. 접착방식 및 수종 간의 유의성 검증 결과 목질재료 유형 $(\mathrm{p}=0.000)$ 간 유의한 차이를 보이는 것으로 나타났다. Type 1 과 Type 2 의 수종 간의 유의한 차이를 보이지 않았다. Type 3 의 경우 층재와 합판의 조합에 따라 다른 결과를 나타냈다. 낙엽송 합판은 미송 층재 $(8.1 \pm 0.5 \mathrm{MPa})$, 육송 합판은 미송 층재 $(6.3 \pm 1.0 \mathrm{MPa})$, 남양재 합판은 낙엽송 층재 $(7.7 \pm 1.2 \mathrm{MPa})$ 로 구성 시 높은 전단강도를 나타냈다.

PVAc 접착제를 사용한 경우 목질재료유형에 따른 전단강도 결과는 Table 4과 같다. PRF 접착제를 사용한 경우와 동일한 결과로 Type $1>$ Type $3>$ Type 2의 유형 순서대로 높은 전단강도를 나타냈다. 접착방식 및 수종 간의 유의성 검증 결과 목질재료유형 $(p=0.000)$ 간 유의한 차이를 보이는 것으로 나타났다. Type 1 과 Type 2 의 수종 간의 유의한 차이를 보이는 것으로 나타났다. Type 1 은 미송, Type 2 는 낙엽송이 더 높은 결과를 나타냈다. Type 3 의 경우 낙엽송을 층재로 사용 시 더 높은 블록전단강도를 나타냈으며 낙엽송 합판 $(8.7 \pm 1.0 \mathrm{MPa})$, 육송 합판 $(6.0 \pm 0.8 \mathrm{MPa})$, 남양재 합판 $(5.8 \pm 0.5 \mathrm{MPa})$ 순서로 높은 전단강도를 나타냈다.

접착제 종류와 목질재료유형의 유의성 검증 결과는 Table 5 와 같으며 목질재료유형 $(\mathrm{p}=0.000)$ 간 유의한 차이를 보이는 것으로 나타났다. Type 1에서 PVAc 접착제 보다 PRF 접착제를 사용 시 더 높은 블록전단강도를 나타냈으나 Type 2 와 Type 3에서는 접착제 종류에 따른 유의한 차이는 나타나지 않았다.

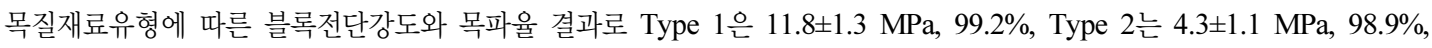
Type 3은 $6.7 \pm 1.4 \mathrm{MPa}, 98.9 \%$ 의 결과를 나타냈다. Type 1은 구조용 집성재로 국내 KS F 3021 에 전단강도는 $7.1 \mathrm{MPa}$ 이상, 목파율 $65 \%$ 로 명시되어 있으며 유럽규격인 $\mathrm{EN} 14080$ 에는 전단강도 $6.0 \mathrm{MPa}$ 이상, 목파율 $90 \%$ 로 명시되어 있다. Type 2 의 CLT 층간 접착 방식은 국내 규격은 마련되어 있지 않으며 유럽 EN 16351 규격 중 전단강도 $1 \mathrm{MPa}$ 로 명시되어 있다. Type 3인 Ply-lam CLT의 제품규격 또한 제정되어 있지 않으며 집성재와 CLT 규격에 의거하여 전단강도 비교를 비교하고자 하였다. Type 3의 전단강도는 평균 $6.7 \pm 1.4 \mathrm{MPa}$ 을 나타냈으며 충족하지 못하는 조건도 있으나 낙엽송 라미나와 합판을 적층 시 유럽 규격(6.0 MPa 이상)과 국내 집성재 규격(7.1 MPa 이상)을 통과한다. 이는 합판의 표층 베니어와 층재가 목리에 따라 평행하게 적층함으로써 기존의 CLT 보다는 더 높은 전단 강도를 나타내는 것으로 판단된다. Ply-lam CLT는 낙엽송 층재와 합판을 적층한 경우 기존의 CLT 보다 높은 전단강도를 가지며 집성재 수준까지 전단강도를 확보할 수 있다.

\section{2. 목질재료 유형에 따른 블록전단강도 파괴 양상}

블록전단강도 시험 이후 시험편의 파괴 양상 분석을 진행하였으며 PRF 접착제는 Table 6, PVAc 접착제는 Table 7에 나타냈 다. 접착제 종류에 따른 차이를 나타내지 않았으며 Type 1은 shear parallel-to-grain, Type 2 는 rolling shear, Type 3 는 shear parallel-to-grain와 rolling shear 파괴가 복합적으로 나타났다. 또한 Type 3 는 층재 파괴 $6 \%$, 합판 파괴 $94 \%$ 로 구성되었으며 주로 합판의 표층 단판이 아닌 섬유 직각방향인 2 번째 층의 단판에서 rolling shear에 의한 파괴가 발생하였다. 접착면의 파괴 양상을 통해 전단강도 값의 저하 요인은 구성 층재와 합판의 단판 두께와 롤링전단과 관계가 있다. CLT의 구성 층재 두께 증가, CLT 두께의 증가됨에 따라 롤링 전단강도가 감소한다고 보고된 바 있다(Sikora et al., 2016).

Type 2 와 Type 3 의 수직 적층된 층재와 단판의 두께 차이로 단판보다 두꺼운 층재를 사용한 Type 2에서 롤링 전단에 의한 블록전단강도 감소에 영향을 미친 것으로 판단된다. 또한 일반적인 롤링 전단은 전단의 $1 / 10$ 수준이며 이는 목리에 수직한 적층구조에 의해 발생되는 롤링에 의하여 전단강도의 감소 요인으로 작용했을 것으로 판단된다(Park et al., 2017; Blass et al., 2000).

본 연구를 통하여 Ply-lam CLT에 대한 최적제조조건을 구명하고자하였다. 구조용 집성재 전단 성능 기준인 7.1 MPa을 통과한 조건으로 PRF 접착제를 사용한 낙엽송 층재-낙엽송 합판, 낙엽송 층재-남양재 합판, 미송 층재-낙엽송 합판 조건과 PVAc 접착제를 사용한 낙엽송 층재-낙엽송 합판 조건을 도출하였다. Ply-lam CLT의 $98 \%$ 이상 목파율 결과로 접착제 도포량은 
Gyu Woong CHOI $\cdot$ Seung Min YANG $\cdot$ Hyun Jae LEE $\cdot$ Jun Ho KIM $\cdot$ Kwang Hyeon CHOI $\cdot$ Seog Goo KANG

$150 \mathrm{~g} / \mathrm{m}^{2}$ 이 최적 조건으로 판단된다.

또한 Ply-lam CLT의 블록전단강도 향상을 위하여 합판의 중층에서 발생되는 rolling shear를 방지하기 위한 합판의 단판 두께, 수종 등에 따른 합판의 롤링 전단성능에 대한 추가적인 연구가 필요할 것으로 판단된다.

\section{4. 결 론}

본 연구에서는 공학목재로써 목구조건축에 주로 사용되는 집성재 및 CLT 그리고 Ply-lam CLT의 블록전단시험을 실시하여 강도 및 파괴 유형을 비교 분석하였다. 이를 통해 Ply-lam CLT의 라미나 및 합판의 수종, 접착제의 종류 및 Layer 구성 등 최적생산을 위한 제조조건을 구명하고자 하였으며 그 결과는 다음과 같다.

1. 집성재, Ply-lam CLT, CLT 순으로 높은 블록전단강도를 나타냈으며 Ply-lam CLT의 구성 중 낙엽송 합판과 낙엽송 라미나의 복합구조는 집성재 전단강도 기준인 $7.1 \mathrm{~N} / \mathrm{mm}^{2}$ 을 통과하였다. 목질재료 유형에 따른 차이는 나타났으나 Ply-lam CLT의 층간 접착제에 따른 차이를 나타내지 않았다. Ply-lam CLT의 최적 제조 조건은 낙엽송 층재와 낙엽송 합판, 남양재 합판을 사용하며 도포량 $150 \mathrm{~g} / \mathrm{m}^{2}$ 으로 사용 용도에 맞게 PRF, PVAc 등 접착제를 선택하여 사용하는 것이 적합할 것으로 판단된다.

2. 목질재료 유형에 따른 전단강도 파괴모드 분석을 통하여 집성재는 shear parallel-to-grain, CLT는 rolling shear, Ply-lam CLT는 합판의 중층에서 shear parallel-to-grain과 rolling shear가 복합적으로 나타나는 것을 확인하였다. 이는 수직 적층된 층재와 단판의 두께 차이로 인하여 Type 2의 롤링강도 감소로 인하여 CLT보다 Ply-lam CLT에서 더 높은 전단 강도를 나타내는 것으로 판단된다.

3. 기존의 CLT 보다 높은 블록전단강도를 나타낸 Ply-lam CLT의 블록전단강도 향상을 위하여 합판의 중층에서 발생되는 rolling shear를 방지하기 위하여 합판의 단판 두께, 수종 등 합판의 롤링 전단을 향상시키기 위한 연구가 추가적으로 필요할 것으로 판단된다. 